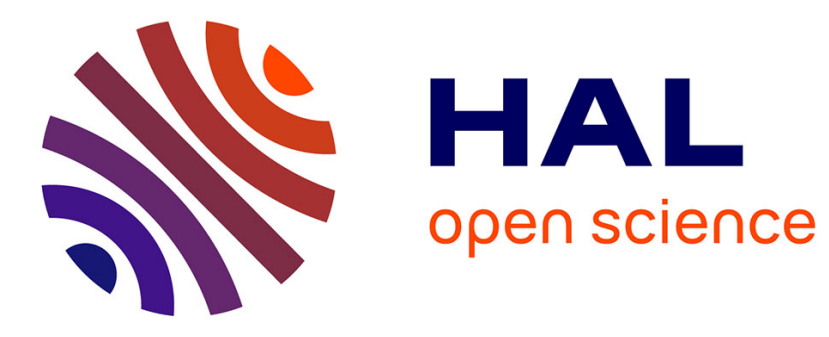

\title{
On Interconnected Observer Design for Nonlinear System
}

Mei Zhang, Ze-Tao Li, Michel Cabassud, Boutaib Dahhou

\section{To cite this version:}

Mei Zhang, Ze-Tao Li, Michel Cabassud, Boutaib Dahhou. On Interconnected Observer Design for Nonlinear System. 2019 International Conference on Modelling, Identification and Control (ICMIC 2019), Jul 2019, Tianjin, China. pp.1313-1323, 10.1007/978-981-15-0474-7_123 . hal-02943938

\section{HAL Id: hal-02943938 \\ https://hal.laas.fr/hal-02943938}

Submitted on 3 Mar 2021

HAL is a multi-disciplinary open access archive for the deposit and dissemination of scientific research documents, whether they are published or not. The documents may come from teaching and research institutions in France or abroad, or from public or private research centers.
L'archive ouverte pluridisciplinaire HAL, est destinée au dépôt et à la diffusion de documents scientifiques de niveau recherche, publiés ou non, émanant des établissements d'enseignement et de recherche français ou étrangers, des laboratoires publics ou privés. 


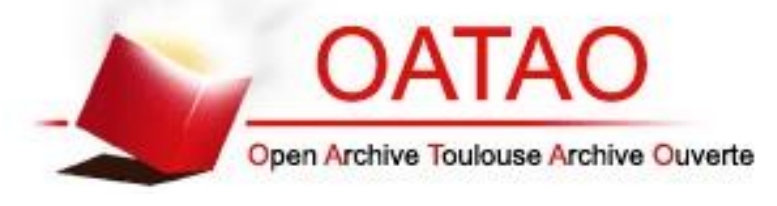

\section{Open Archive Toulouse Archive Ouverte}

OATAO is an open access repository that collects the work of Toulouse researchers and makes it freely available over the web where possible

This is an author's version published in: https://oatao.univ-toulouse.fr/25954

Official URL :

https://doi.org/10.1007/978-981-15-0474-7 123

\section{To cite this version:}

Zhang, Mei and Li, Ze-tao and Cabassud, Michel and Dahhou, Boutaïeb On Interconnected Observer Design for Nonlinear System. (2019) In: 2019 International Conference on Modelling, Identification and Control (ICMIC 2019), 13 July 2019 - 15 July 2019 (Tianjin, China).

Any correspondence concerning this service should be sent to the repository administrator: tech-oatao@listes-diff.inp-toulouse.fr 


\title{
On Interconnected Observer Design for Nonlinear System
}

\author{
Mei Zhang, Ze-tao Li, Michel Cabassud and Boutaïeb Dahhou
}

\begin{abstract}
This paper investigates the possibility of decomposing a control system into an interconnection of actuator and process subsystems; this allows monitoring the properties of the interconnected system globally and locally. For that, observer for the nonlinear interconnected system is studied. Specially, the interconnection between the two subsystems is assumed to be inaccessible to measurement. The aim is then to accurately estimate online the states vector of each subsystem, as well as the unknown interconnection. Numerical simulations confirm the effectiveness of the designed observer.
\end{abstract}

Keywords Interconnected system - Unknown interconnection - States estimation • Left invertibility $\cdot$ Actuator subsystem $\cdot$ Process subsystem

\section{Introduction}

In practice, interconnected dynamical systems appear in many control applications whether naturally or intentionally due to control design purpose. An interconnected system consists of a series of interconnected dynamical units, and therefore exhibits very complicate dynamics [1].

M. Zhang · Z. Li ( $\otimes)$

Electrical Engineering School, Guizhou University, Guiyang 550025, China

e-mail: gzulzt@163.com

M. Zhang

e-mail: mei.zhang@ensiacet.fr

M. Cabassud

CNRS, LGC, 31030 Toulouse, France

e-mail: michel.cabassud@ensiacet.fr

Université de Toulouse, UPS, LGC, 31030 Toulouse, France

B. Dahhou

CNRS, LAAS, 31400 Toulouse, France

e-mail: boutaib.dahhou@laas.fr

Université de Toulouse, UPS, LAAS, 31400 Toulouse, France

https://doi.org/10.1007/978-981-15-0474-7_123 
Over the past years, the topic of states estimation for interconnected system has received extensively attention in the literature, see e.g. in [1-3]. A large number of publications focused on this problem with satisfactory results are in a centralized manner, resulting in various types of observers like high gain observer [3], sliding mode observer [4], adaptive observer [5] etc. However, note that a centralized observer may not be practical for the interconnected systems due to the complexity of implementation, and the state or parts of the state cannot be measured due to uneconomic measurement costs or physical circumstances like high temperatures, where no measurement equipment is available, for example. A solution to overcome this difficulty is to decompose the systems into an interconnection of several subsystems so that the observers can be designed in a decentralized manner. A typical approach of state estimation is to design observers for each subsystem individually and the overall estimator is formed by gathering of all the observers, different kinds of methodologies are developed, like in [6-9].

With respect to the above mentioned methods, one major challenge is the availability of the measurement of the interconnections between subsystems. For example, the output of the actuator can be either uneconomic or unrealistic to measure its output. A promising approach was reported in [10] where the problem of state-observation is addressed for nonlinear systems that modeled by an ODE-PDE series association. This problem has also been studied for interconnected system formed by a nonlinear system followed by a linear system, like in [8].

This paper considers the issues of both state and unknown interconnection estimation for the interconnected system represented by two nonlinear associations connected in series. Two underlying issues are worth to be highlighted to better understand the nature of the considered estimation problem. Firstly, the measurement output used in the observer of former subsystem is assumed not accessible; the solution is to replace it by an estimate via observer of latter subsystem. Secondly, in the latter subsystem, the estimated interconnection that provided for the previous subsystem is treated as an additional state, forming a new extended subsystem; and expression for the new state is obtained by computing derivatives of output equation of the previous subsystem.

\section{Motivations and Problem Formulations}

The problem of states observation is addressed for nonlinear systems that can be modeled by two interconnected nonlinear dynamical units, the actuator and the process subsystems, as shown in Fig. 1. The aim is to accurately estimate the states

Fig. 1 Interconnected system structure

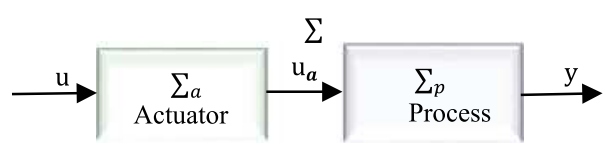


vector of both subsystems, as well as the interconnection.

We consider a dynamical process subsystem as an input affine form:

$$
\sum_{\mathrm{p}}:\left\{\begin{array}{l}
\dot{\mathrm{x}}=f(\mathrm{x})+g(x) \mathrm{u}_{\mathrm{a}}, x\left(\mathrm{t}_{0}\right)=\mathrm{x}_{0} \\
y=h(\mathrm{x})
\end{array}\right.
$$

where $\mathrm{x} \in \mathfrak{R}^{\mathrm{n}}$ is the state of the process subsystem, $\mathrm{y} \in \mathfrak{R}^{\mathrm{p}}$ is the output of the global system, which is also the output of the process subsystem. $u_{\mathrm{a}} \in \Re^{\mathrm{m}}$ is the input of process subsystem, which is also the output of the actuator subsystem. $\mathrm{u}_{\mathrm{a}}$ is assumed to be inaccessible. $\mathrm{f}$ and $\mathrm{g}$ are smooth vector field on $\mathfrak{R}^{\mathrm{n}}$ and $\mathrm{h}$ is smooth vector field on $\mathfrak{R}^{\mathrm{p}}$.

An input affine structure is also assumed for the actuator subsystem:

$$
\sum_{a}:\left\{\begin{array}{l}
\dot{\mathrm{x}}_{\mathrm{a}}=\mathrm{f}_{\mathrm{a}}\left(\mathrm{x}_{\mathrm{a}}\right)+\mathrm{g}_{\mathrm{a}}\left(\mathrm{x}_{\mathrm{a}}\right) \mathrm{u}, \quad \mathrm{x}_{\mathrm{a}}\left(\mathrm{t}_{0}\right)=\mathrm{x}_{\mathrm{a} 0} \\
\mathrm{u}_{\mathrm{a}}=\mathrm{h}_{\mathrm{a}}\left(\mathrm{x}_{\mathrm{a}}\right)
\end{array}\right.
$$

where $\mathrm{x}_{a} \in \mathfrak{R}^{\mathrm{n}}$ is the state, $\mathrm{u} \in \mathfrak{R}^{1}$ is the input, $\mathrm{u}_{\mathrm{a}} \in \mathrm{R}^{\mathrm{m}}$ is the output of the actuator subsystem, which is also the input of the process subsystem. $f_{a}$ and $g_{a}$ are smooth vector field on $\Re^{\mathrm{n}}$ and $\mathrm{h}$ is smooth vector field on $\Re^{\mathrm{m}}$.

Considering interconnected system depicted by (1) and (2), it is desirable to monitor the performance of the interconnected system with aspect to individual subsystems and the overall system. However, the major difficulty for employing the existing methods is to satisfy the assumption that inputs and outputs of each subsystem are available, since the connection point between the two blocks is not accessible to measurement. This is because the connection is the output of the actuator subsystem where online measurement is either difficult to obtain due to physical reasons or the measurement is uneconomical since actuators are often far from the controller. As shown in Fig. 1, the particular aim in our design is to accurately estimate online the state vector $\mathrm{x}$ and $\mathrm{x}_{\mathrm{a}}$ of each subsystem, as well as the unmeasured interconnection vector $\mathrm{u}_{\mathrm{a}}$.

\section{Interconnected Observer Design}

The structure of the proposed observer is depicted as a two level interconnected observer system which consists of two state estimators, the actuator and the process state estimators. The specific idea of the proposed interconnected observer is as follows. First, an existing observer is supposed to be already available for the nonlinear subsystem $\sum_{\mathrm{a}}$ with measured output $\mathrm{u}_{\mathrm{a}}$, then we implement that observer using an estimate of $\mathrm{u}_{\mathrm{a}}$, denoted by $\tilde{\mathrm{u}}_{\mathrm{a}}$. In order to produce such an estimate, we extend the state space of the process subsystem $\sum_{\mathrm{p}}$ to include $\mathrm{u}_{\mathrm{a}}$ as an additional state. By computing derivatives of $\mathrm{u}_{\mathrm{a}}$ in actuator subsystem, we can obtain an expression corresponding to times derivatives of the output $\mathrm{u}_{\mathrm{a}}$ which is a function of $\mathrm{u}$, derivatives 
of $\mathrm{u}$ and $\mathrm{x}_{\mathrm{a}}$. Then an observer is constructed for this extended process subsystem. State estimator of actuator subsystem, together with state estimator of process subsystem, a kind of interconnected observer designed method is then proposed for the studied interconnected nonlinear system.

\subsection{Observer Design for the Interconnected System}

First, consider a converging observer for actuator subsystem is:

$$
\left\{\begin{array}{l}
\dot{\hat{x}}_{\mathrm{a}}=\mathrm{f}_{\mathrm{a}}\left(\hat{\mathrm{x}}_{\mathrm{a}}\right)+\mathrm{g}_{\mathrm{a}}\left(\hat{\mathrm{x}}_{\mathrm{a}}\right) \mathrm{u}+\mathrm{k}_{\mathrm{a}}\left(g_{\mathrm{a}}, \hat{\mathrm{x}}_{\mathrm{a}}\right)\left(\mathrm{h}_{\mathrm{a}}\left(\hat{\mathrm{x}}_{\mathrm{a}}\right)-\mathrm{u}_{\mathrm{a}}\right) \\
\dot{g}_{\mathrm{a}}=\mathrm{G}_{\mathrm{a}}\left(\hat{\mathrm{x}}_{\mathrm{a}}, \mathrm{u}, g_{\mathrm{a}}\right)
\end{array}\right.
$$

where $\mathrm{k}_{\mathrm{a}}, \mathrm{G}_{\mathrm{a}}$ are smooth gain functions with respect to their arguments. $\mathrm{G}_{\mathrm{a}}$ is a subset of $\Re^{\mathrm{n}}$. To this end, introduce the state estimation error as:

$$
\mathrm{e}_{a}:=\mathrm{x}_{a}-\hat{\mathrm{x}}_{a}
$$

Then subtracting corresponding equation of (2) and (3), we get the following error dynamics as:

$$
\dot{\mathrm{e}}_{\mathrm{a}}\left(\mathrm{t}, \mathrm{e}_{\mathrm{a}}\right)=\mathrm{f}_{\mathrm{a}}\left(\mathrm{x}_{\mathrm{a}}\right)+\mathrm{g}_{\mathrm{a}}\left(\mathrm{x}_{\mathrm{a}}\right) \mathrm{u}-\mathrm{f}_{\mathrm{a}}\left(\hat{\mathrm{x}}_{\mathrm{a}}\right)-\mathrm{g}_{\mathrm{a}}\left(\hat{\mathrm{x}}_{\mathrm{a}}\right) \mathrm{u}-\mathrm{K}\left(\mathrm{u}, \hat{\mathrm{x}}_{\mathrm{a}}, \mathrm{u}_{\mathrm{a}}\right)
$$

where $\mathrm{K}\left(\mathrm{u}, \hat{\mathrm{x}}_{\mathrm{a}}, \mathrm{u}_{\mathrm{a}}\right)=\mathrm{k}_{\mathrm{a}}\left(g_{\mathrm{a}}, \hat{\mathrm{x}}_{\mathrm{a}}\right)\left(\mathrm{h}_{\mathrm{a}}\left(\hat{\mathrm{x}}_{\mathrm{a}}\right)-\mathrm{u}_{\mathrm{a}}\right)$..

The observer defined by (3) could be implemented on condition that $\mathrm{u}_{a}$ is accessible, but it is not the fact in the case. Since $\mathrm{u}_{a}$ in our design represents the output of the actuator subsystem which is assumed unmeasured, therefore we have to replace $\mathrm{u}_{\mathrm{a}}$ with an estimated $\tilde{\mathrm{u}}_{\mathrm{a}}$ by the available measurements.

$$
\left\{\begin{array}{l}
\dot{\hat{\mathrm{x}}}_{\mathrm{a}}=\mathrm{f}_{\mathrm{a}}\left(\hat{\mathrm{x}}_{\mathrm{a}}\right)+\mathrm{g}_{\mathrm{a}}\left(\hat{\mathrm{x}}_{\mathrm{a}}\right) \mathrm{u}+\mathrm{k}_{\mathrm{a}}\left(g_{\mathrm{a}}, \hat{\mathrm{x}}_{\mathrm{a}}\right)\left(\mathrm{h}_{\mathrm{a}}\left(\hat{\mathrm{x}}_{\mathrm{a}}\right)-\tilde{\mathrm{u}}_{\mathrm{a}}\right) \\
\dot{g}_{\mathrm{a}}=\mathrm{G}_{\mathrm{a}}\left(\hat{\mathrm{x}}_{\mathrm{a}}, \mathrm{u}, g_{\mathrm{a}}\right)
\end{array}\right.
$$

denote $\mathrm{K}\left(\mathrm{u}, \hat{\mathrm{x}}_{\mathrm{a}}, \tilde{\mathrm{u}}_{\mathrm{a}}\right)=\mathrm{k}_{\mathrm{a}}\left(g_{\mathrm{a}}, \hat{\mathrm{x}}_{\mathrm{a}}\right)\left(\mathrm{h}_{\mathrm{a}}\left(\hat{\mathrm{x}}_{\mathrm{a}}\right)-\tilde{\mathrm{u}}_{\mathrm{a}}\right)$.

We seek again estimation error by subtracting corresponding equation in (2) and (5), thus yielding the new error dynamics as follows:

$$
\dot{\tilde{\mathrm{e}}}_{a}\left(t, \tilde{e}_{a}\right)=\dot{\mathrm{e}}_{a}\left(t, e_{a}\right)+\mathrm{K}\left(\mathrm{u}, \hat{\mathrm{x}}_{a}, \mathrm{u}_{a}\right)-\mathrm{K}\left(\mathrm{u}, \hat{\mathrm{x}}_{a}, \tilde{\mathrm{u}}_{\mathrm{a}}\right)
$$

In order to ensure exponential stability of the error dynamics (6), we need an assumption regarding the sensitivity of $\mathrm{K}\left(\mathrm{u}, \hat{\mathrm{x}}_{\mathrm{a}}, \mathrm{u}_{\mathrm{a}}\right)$ with respect to changes in $\mathrm{u}_{\mathrm{a}}$. The following Assumption provides a sufficient condition for achieving this purpose. This subject of following statement is inspired by [8]. 
Assumption 1 for any $\mathrm{u} \in \mathbb{U},\left(\mathrm{t}, \hat{\mathrm{x}}_{\mathrm{a}}, \hat{\mathrm{u}}_{\mathrm{a}}\right) \in \mathcal{A} \cdot \mathcal{C}\left(\mathbb{R}^{+}, \mathbb{R}\right)$, there exists a real constant $\gamma_{3}$ satisfies:

$$
\left\|\mathrm{K}\left(\mathrm{u}, \hat{\mathrm{x}}_{\mathrm{a}}, \mathrm{u}_{\mathrm{a}}\right)-\mathrm{K}\left(\mathrm{u}, \hat{\mathrm{x}}_{\mathrm{a}}, \tilde{\mathrm{u}}_{\mathrm{a}}\right)\right\| \leq \gamma_{3}\left\|\mathrm{u}_{\mathrm{a}}-\tilde{\mathrm{u}}_{\mathrm{a}}\right\|
$$

Assumption 2 implies that the definition of $\dot{\tilde{e}}_{\mathrm{a}}\left(\mathrm{t}, \tilde{\mathrm{e}}_{\mathrm{a}}\right)$ in (6) is not affected.

Theorem 1 if Assumption 1 is satisfied, then the observer described in (5) is an exponential observer for the actuator subsystem described in (2).

\subsection{State Estimator Design for Process Subsystem}

In order to produce an observer for the process subsystem (1) subject to unknown inputs, we solve this problem by extending this unknown input as an additional state, and propose an observer for the extended system.

Let:

$$
\mathrm{x}_{\mathrm{u}} \triangleq \mathrm{u}_{\mathrm{a}} \dot{\mathrm{x}}_{\mathrm{u}}=\dot{\mathrm{u}}_{\mathrm{a}}
$$

According to [8], we define a function $\varepsilon\left(\mathrm{u}, \dot{\mathrm{u}}, \mathrm{x}_{\mathrm{a}}\right)$ with respect to the time derivative of the output $\mathrm{u}_{\mathrm{a}}$ in (2).

$$
\dot{\mathrm{x}}_{\mathrm{u}}=\varepsilon\left(\mathrm{u}, \dot{\mathrm{u}}, \mathrm{x}_{\mathrm{a}}\right)=\frac{\partial \mathrm{h}_{\mathrm{a}}}{\partial \mathrm{u}}\left(\mathrm{u}, \mathrm{x}_{\mathrm{a}}\right) \dot{\mathrm{u}}+\frac{\partial \mathrm{h}_{\mathrm{a}}}{\partial \mathrm{x}_{\mathrm{a}}}\left(\mathrm{u}, \mathrm{x}_{\mathrm{a}}\right) \mathrm{f}_{\mathrm{a}}\left(\mathrm{u}, \mathrm{x}_{\mathrm{a}}\right)
$$

Assumption 2 For any $\mathrm{u} \in \mathbb{U},\left(\mathrm{t}, \hat{\mathrm{x}}_{\mathrm{a}}\right) \in \mathcal{A} \cdot \mathcal{C}\left(\mathbb{R}^{+}, \mathbb{R}\right)$, there exists a real constant $\gamma_{4}$ satisfies:

$$
\left\|\varepsilon\left(\mathrm{u}, \dot{\mathrm{u}}, \hat{\mathrm{x}}_{\mathrm{a}}\right)-\varepsilon\left(\mathrm{u}, \dot{\mathrm{u}}, \mathrm{x}_{\mathrm{a}}\right)\right\| \leq \gamma_{4}\left\|\mathrm{x}_{\mathrm{a}}-\hat{\mathrm{x}}_{\mathrm{a}}\right\|
$$

Similar to Assumptions 1 and 2 implies global Lipchitz-type condition on function $\varepsilon$, and it can also be replaced by local smoothness condition since $\mathrm{u}, \dot{\mathrm{u}}, \mathrm{x}_{\mathrm{a}}$ are bounded in physical problem.

Then new actuator and new process subsystem can be expressed as:

$$
\sum_{p}:\left\{\begin{array}{l}
\dot{\mathrm{x}}=f(\mathrm{x})+g(\mathrm{x}) \mathrm{x}_{\mathrm{u}} \\
\dot{\mathrm{x}}_{\mathrm{u}}=\varepsilon\left(\mathrm{u}, \dot{\mathrm{u}}, \mathrm{x}_{\mathrm{a}}\right)
\end{array}\right.
$$

Define $\mathrm{z}=\left[\begin{array}{ll}\mathrm{z}_{1} & \mathrm{z}_{2}\end{array}\right]=\left[\begin{array}{ll}\mathrm{x} \mathrm{x}_{\mathrm{u}}\end{array}\right]$, then system (9) can be extended as:

$$
\left\{\begin{array}{l}
\dot{\mathrm{z}}=1\left(\mathrm{z}_{1}\right) \mathrm{G}\left(\mathrm{z}_{1}\right) \mathrm{z}+\mathrm{F}\left(\mathrm{z}_{1}\right)+\bar{\varepsilon}\left(\mathrm{u}, \dot{\mathrm{u}}, \mathrm{x}_{\mathrm{a}}\right) \\
\mathrm{y}=\mathrm{Cx}
\end{array}\right.
$$




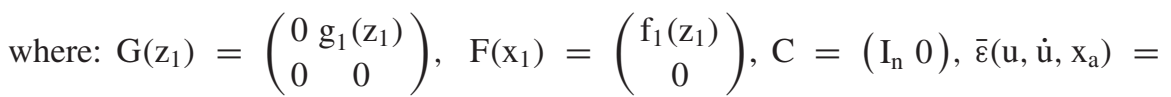
$\left[0 \varepsilon\left(\mathrm{u}, \dot{\mathrm{u}}, \mathrm{x}_{\mathrm{a}}\right)\right]^{\mathrm{T}}, \mathrm{I}_{\mathrm{n}}$ is $\mathrm{n} \times \mathrm{n}$ identity matrix, $\mathrm{l}\left(\mathrm{z}_{1}\right)$ is a scalar real function with respect to their arguments and $\alpha_{1} \leq\left|1\left(\mathrm{z}_{1}\right)\right| \leq \beta_{1}$.

An extended high gain observer for (10) can be given in the following way:

$$
\left\{\begin{array}{l}
\dot{\hat{z}}=l\left(\hat{\mathrm{z}}_{1}\right) G\left(\hat{\mathrm{z}}_{1}\right) \hat{\mathrm{z}}+F\left(\hat{\mathrm{z}}_{1}\right)+\bar{\varepsilon}\left(\mathrm{u}, \dot{\mathrm{u}}, \hat{\mathrm{x}}_{\mathrm{a}}\right)+H\left(\hat{\mathrm{z}}_{1}\right)(\hat{\mathrm{y}}-\mathrm{y}) \\
\hat{\mathrm{y}}=C \hat{\mathrm{z}}
\end{array}\right.
$$

where: $\mathrm{H}=\left[\begin{array}{ll}\mathrm{H}_{\mathrm{z}_{1}} & \mathrm{H}_{\mathrm{z}_{2}}\end{array}\right]^{\mathrm{T}}=\Lambda^{-1}\left(\hat{\mathrm{z}}_{1}\right) \mathrm{S}_{\theta}^{-1} \mathrm{C}^{\mathrm{T}}, \Lambda\left(\hat{\mathrm{z}}_{1}\right)=\left[\begin{array}{cc}\mathrm{I} & 0 \\ 0 & \mathrm{G}_{1}\left(\hat{\mathrm{z}}_{1}\right)\end{array}\right]$

\subsection{Interconnected Observer}

System (5), together with (11), constitutes the interconnected observer for the studied interconnected system, as follows:

$$
\left\{\begin{array}{l}
\dot{\hat{\mathrm{x}}}_{\mathrm{a}}=\mathrm{f}_{\mathrm{a}}\left(\hat{\mathrm{x}}_{\mathrm{a}}, \mathrm{u}\right)+\mathrm{k}_{\mathrm{a}}\left(\mathrm{g}_{\mathrm{a}}, \hat{\mathrm{x}}_{\mathrm{a}}\right)\left(\mathrm{h}_{\mathrm{a}}\left(\hat{\mathrm{x}}_{\mathrm{a}}\right)-\hat{\mathrm{z}}_{2}\right) \\
\dot{\hat{\mathrm{z}}}=l\left(\hat{\mathrm{z}}_{1}\right) G\left(\hat{\mathrm{z}}_{1}\right) \hat{\mathrm{z}}+F\left(\hat{\mathrm{z}}_{1}\right)+\bar{\varepsilon}\left(\mathrm{u}, \dot{\mathrm{u}}, \hat{\mathrm{x}}_{\mathrm{a}}\right)+H\left(\hat{\mathrm{z}}_{1}\right)(\hat{\mathrm{y}}-\mathrm{y})
\end{array}\right.
$$

where virtual measurement $\tilde{\mathrm{u}}_{a}$ in (6) is replaced by its estimation $\hat{\mathrm{z}}_{2}$.

\section{Numerical Simulations Result}

In order to test the performance of the proposed observers, A case study is developed on an intensified HEX reactor. More relative information could be found in [11].

\subsection{System Modelling}

The actuator subsystem model is described as: $\mathrm{x}_{\mathrm{a}}^{\mathrm{T}}=\left[\begin{array}{llll}\mathrm{x}_{\mathrm{a} 1} & \mathrm{x}_{\mathrm{a} 2} & \mathrm{x}_{\mathrm{a} 3} & \mathrm{X}_{\mathrm{a} 4}\end{array}\right]=$ $\left[\mathrm{X}_{1} \frac{\mathrm{dX}_{1}}{\mathrm{dt}} \mathrm{X}_{2} \frac{\mathrm{dX}_{2}}{\mathrm{dt}}\right], \mathrm{u}^{\mathrm{T}}=\left[\mathrm{u}_{1} \mathrm{u}_{2}\right]=\left[\mathrm{p}_{\mathrm{c} 1} \mathrm{p}_{\mathrm{c} 2}\right], \mathrm{u}_{\mathrm{a}}^{\mathrm{T}}=\left[\begin{array}{ll}\mathrm{F}_{1} & \mathrm{~F}_{2}\end{array}\right]=$ $\left[\mathrm{C}_{\mathrm{v}} \sqrt{\frac{\Delta \mathrm{P}_{1}}{\mathrm{sg}}} \mathrm{X}_{1} \mathrm{C}_{\mathrm{v}} \sqrt{\frac{\Delta \mathrm{P}_{2}}{\mathrm{sg}}} \mathrm{X}_{2}\right], C=\left[\begin{array}{llll}c_{1} & c_{2} & c_{3} & c_{4}\end{array}\right]=\left[\mathrm{C}_{\mathrm{v}} \sqrt{\frac{\Delta \mathrm{P}_{1}}{\mathrm{sg}}} 0 \mathrm{C}_{\mathrm{v}} \sqrt{\frac{\Delta \mathrm{P}_{2}}{\mathrm{sg}}} 0\right]$

where $\mathrm{F}$ is flow rate $\left(\mathrm{m}^{3} \mathrm{~s}^{-1}\right), \Delta \mathrm{P}$ is the fluid pressure drop across the valve $(\mathrm{Pa})$, sg is specific gravity of fluid, $X$ is the valve opening, $C_{v}$ is valve coefficient $A_{a}$ is the diaphragm area, $p_{c}$ is the pneumatic pressure, $m$ is the mass of the control valve stem, $\mu$ is the friction of the valve stem, $\mathrm{k}$ is the spring compliance, the actuator 
subsystem is then described as:

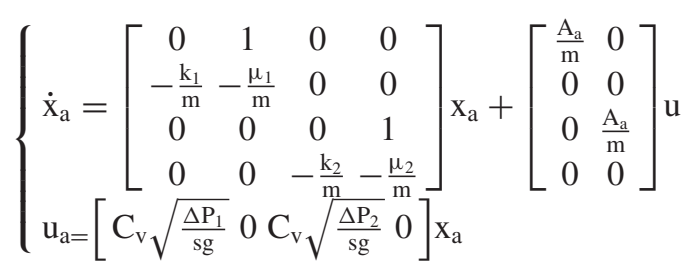

For the process subsystem, define the state vector as $\mathrm{x}^{\mathrm{T}}=\left[\mathrm{x}_{1}, \mathrm{x}_{2}\right]^{\mathrm{T}}=\left[\mathrm{T}_{\mathrm{p}}, \mathrm{T}_{\mathrm{u}}\right]^{\mathrm{T}}$, the control input $u_{a}^{T}=\left[u_{a 1}, u_{a 2}\right]^{T}=\left[F_{p}, F_{u}\right]^{T}$, the output vector of measurable variables $\mathrm{y}^{\mathrm{T}}=\left[\mathrm{y}_{1}, \mathrm{y}_{2}\right]^{\mathrm{T}}=\left[\mathrm{T}_{\mathrm{p}}, \mathrm{T}_{\mathrm{u}}\right]^{\mathrm{T}}$, where $\rho_{\mathrm{p}}, \rho_{\mathrm{u}}$ are density of the process fluid and utility fluid (in $\mathrm{kg} \mathrm{m}^{-3}$ ) $, \mathrm{V}_{\mathrm{p}}, \mathrm{V}_{\mathrm{u}}$ are volume of the process fluid and utility fluid (in $\mathrm{m}^{3}$ ), $\mathrm{c}_{\mathrm{pp}}, \mathrm{c}_{\mathrm{pu}}$ are specific heat of the process fluid and utility fluid (in $\mathrm{J} \mathrm{kg}^{-1} \mathrm{~K}^{-1}$ ), $\mathrm{U}$ is the overall heat transfer coefficient (in $\mathrm{J} \mathrm{m}^{-2} \mathrm{~K}^{-1} \mathrm{~s}^{-1}$ ). A is the reaction area (in $\mathrm{m}^{2}$ ). $\mathrm{F}_{\mathrm{p}}, \mathrm{F}_{\mathrm{u}}$ are mass flowrate of process fluid and utility fluid (in $\mathrm{kg} \mathrm{s}^{-1}$ ). $\mathrm{T}_{\mathrm{p}}$ is the process fluid temperature. $T_{u}$ is the utility fluid temperature of previous cell. $T_{p i}, T_{u i}$ are the inlet temperature of process fluid and utility fluid.

Then the process subsystem can be described in the following state-space form:

$$
\left\{\begin{array}{l}
\dot{\mathrm{x}}=\mathrm{f}(\mathrm{x})+\sum_{\mathrm{i}=1}^{2} \mathrm{~g}_{\mathrm{i}}(\mathrm{x}) \mathrm{u}_{\mathrm{a}} \\
y=\mathrm{h}\left(\mathrm{x}, \mathrm{u}_{\mathrm{a}}\right)
\end{array}\right.
$$

where $f(x)=\left(\begin{array}{l}f_{1}(x) \\ f_{2}(x)\end{array}\right)=\left(\begin{array}{c}\frac{h_{p} A}{\rho_{p} C_{p} V_{p}}\left(T_{p}-T_{u}\right) \\ \frac{h_{u} A}{\rho_{u} C_{p u} V_{u}}\left(T_{u}-T_{p}\right)\end{array}\right)$, and $g(x)=\left(g_{1}, g_{2}\right)=$ $\left(\begin{array}{cc}\frac{\left(T_{\mathrm{p} i}-\mathrm{T}_{\mathrm{p}}\right)}{\mathrm{V}_{\mathrm{p}}} & 0 \\ 0 & \frac{\left(T_{\mathrm{ui}}-\mathrm{T}_{\mathrm{u}}\right)}{\mathrm{V}_{\mathrm{u}}}\end{array}\right), \mathrm{y}_{1}=\mathrm{x}_{1}, \mathrm{y}_{2}=\mathrm{x}_{2}$.

By using (8), we can obtain a function for the derivatives for $\mathrm{u}_{\mathrm{a}}$ :

$$
\begin{aligned}
\dot{\mathrm{u}}_{\mathrm{a}} & =\varepsilon\left(\mathrm{u}, \dot{\mathrm{u}}, \mathrm{x}_{\mathrm{a}}\right)=\frac{\partial \mathrm{h}_{\mathrm{a}}}{\partial \mathrm{u}}\left(\mathrm{u}, \mathrm{x}_{\mathrm{a}}\right) \dot{\mathrm{u}}+\frac{\partial \mathrm{h}_{\mathrm{a}}}{\partial \mathrm{x}_{\mathrm{a}}}\left(\mathrm{u}, \mathrm{x}_{\mathrm{a}}\right) \mathrm{f}_{\mathrm{a}}\left(\mathrm{u}, \mathrm{x}_{\mathrm{a}}\right) \\
& =\left(\mathrm{C}_{\mathrm{v}} \sqrt{\frac{\Delta \mathrm{P}_{1}}{\mathrm{sg}}} 0 \mathrm{C}_{\mathrm{v}} \sqrt{\frac{\Delta \mathrm{P}_{2}}{\mathrm{sg}}} 0\right) \mathrm{x}_{\mathrm{a}}+\left(\frac{\mathrm{A}_{\mathrm{a}}}{\mathrm{m}} \mathrm{C}_{\mathrm{v}} \sqrt{\frac{\Delta \mathrm{P}_{1}}{\mathrm{sg}}} \frac{\mathrm{A}_{\mathrm{a}}}{\mathrm{m}} \mathrm{C}_{\mathrm{v}} \sqrt{\frac{\Delta \mathrm{P}_{2}}{\mathrm{sg}}}\right) \mathrm{u}
\end{aligned}
$$

Define the state vector as $\mathrm{x}_{1}^{\mathrm{T}}=\left[\mathrm{x}_{11}, \mathrm{x}_{12}\right]^{\mathrm{T}}=\left[\mathrm{T}_{\mathrm{p}}, \mathrm{T}_{\mathrm{u}}\right]^{\mathrm{T}}$, unmeasured state $\mathrm{x}_{2}^{\mathrm{T}}=$ $\left[\mathrm{x}_{21}, \mathrm{x}_{22}\right]^{\mathrm{T}}=\left[\mathrm{u}_{\mathrm{a} 1}, \mathrm{u}_{\mathrm{a} 2}\right]^{\mathrm{T}}=\left[\mathrm{F}_{\mathrm{p}}, \mathrm{F}_{\mathrm{u}}\right]^{\mathrm{T}}$, the output vector of measurable variables $\mathrm{y}^{\mathrm{T}}=\left[\mathrm{y}_{1}, \mathrm{y}_{2}\right]^{\mathrm{T}}=\left[\mathrm{T}_{\mathrm{p}}, \mathrm{T}_{\mathrm{u}}\right]^{\mathrm{T}}$, then the Eqs. (14) and (15) can be rewritten in the following state-space form: 


$$
\left\{\begin{array}{l}
\dot{\mathrm{x}}_{1}=\mathrm{G}_{1}\left(\mathrm{x}_{1}\right) \mathrm{x}_{2}+\mathrm{g}_{1}\left(\mathrm{x}_{1}, u\right) \\
\dot{\mathrm{x}}_{2}=\varepsilon\left(\mathrm{u}, \dot{\mathrm{u}}, \mathrm{x}_{\mathrm{a}}\right) \\
y=\mathrm{x}_{1}
\end{array}\right.
$$

where, $\mathrm{G}_{1}\left(\mathrm{x}_{1}\right)=\left(\begin{array}{cc}\frac{\left(\mathrm{T}_{\mathrm{pi}}-\mathrm{x}_{11}\right)}{\mathrm{V}_{\mathrm{p}}} & 0 \\ 0 & \frac{\left(\mathrm{T}_{\mathrm{ui}}-\mathrm{x}_{12}\right)}{\mathrm{V}_{\mathrm{u}}}\end{array}\right)$, and $\mathrm{f}_{1}(\mathrm{x})=\left(\begin{array}{c}\frac{\mathrm{h}_{\mathrm{p}} \mathrm{A}}{\rho_{\mathrm{p}} \mathrm{C}_{\mathrm{pp}} \mathrm{V}_{\mathrm{p}}}\left(\mathrm{x}_{11}-\mathrm{x}_{12}\right) \\ \frac{\mathrm{h}_{\mathrm{u}} \mathrm{A}}{\rho_{\mathrm{u}} \mathrm{C}_{\mathrm{pu}} \mathrm{V}_{\mathrm{u}}}\left(\mathrm{x}_{12}-\mathrm{x}_{11}\right)\end{array}\right)$.

\subsection{Simulation Results}

Numerical simulations were carried out. Considering the actuator and process model given by (13) and (16), observers (12) were designed for estimating unmeasured inlet flows $F_{p}, F_{u}$, and monitoring performance final product $T_{p}, T_{u}$. An initial value $\mathrm{F}_{\mathrm{u}}=4.22 \mathrm{e}^{-5} \mathrm{~m}^{3} \mathrm{~s}^{-1}$, and $\mathrm{F}_{\mathrm{p}}=4.17 \mathrm{e}^{-6} \mathrm{~m}^{3} \mathrm{~s}^{-1}$ were considered, then followed by an abrupt change of $\mathrm{F}_{\mathrm{u}} \mathrm{t}=60 \mathrm{~s}$. After that, at $\mathrm{t}=100 \mathrm{~s}, \mathrm{~F}_{\mathrm{p}}$ begins to deteriorate. Simulation Results are illustrated in Figs. 2, 3, 4 and 5.

From Figs. 2 and 3, after a short transient time, the estimated outlet fluid temperature $\hat{\mathrm{T}}_{\mathrm{p}}$ and $\hat{\mathrm{T}}_{\mathrm{u}}$ in dash line give an accurate estimation value to the measurement $\mathrm{T}_{\mathrm{p}}$ and $\mathrm{T}_{\mathrm{u}}$ in solid line. At $60 \mathrm{~s}$, the estimated $\hat{\mathrm{T}}_{\mathrm{p}}$ unexpectedly decrease, and finally it stabilizes at a new level, a drop of $0.2{ }^{\circ} \mathrm{C}$ is occurred, then another drops happens at $\mathrm{t}=100 \mathrm{~s}$ before it reaches the new stable level with another $0.9^{\circ} \mathrm{C}$ reduction. The
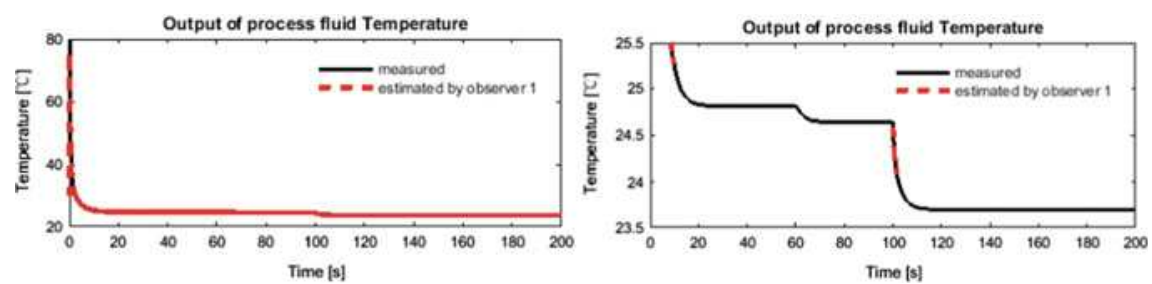

Fig. 2 Outlet temperature of process fluid, solid line denotes measured value $T_{p}$ while dash line is the estimated one $\hat{\mathrm{T}}_{\mathrm{p}}$
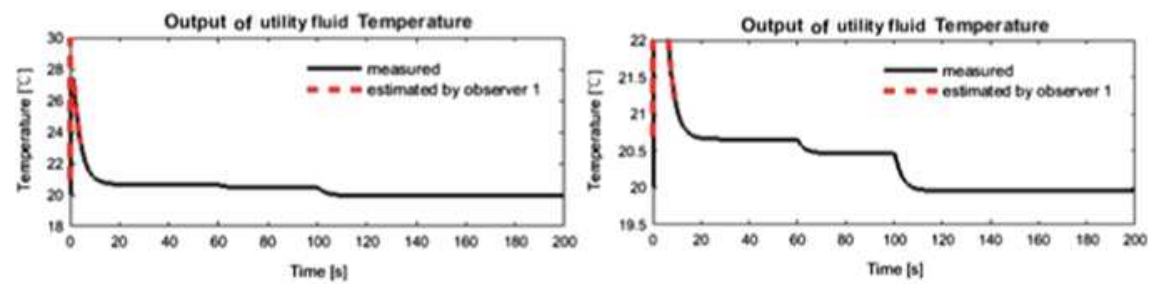

Fig. 3 Outlet temperature of utility fluid, solid line denotes measured value $T_{u}$ while dash line is the estimated one $\hat{T}_{u}$ 

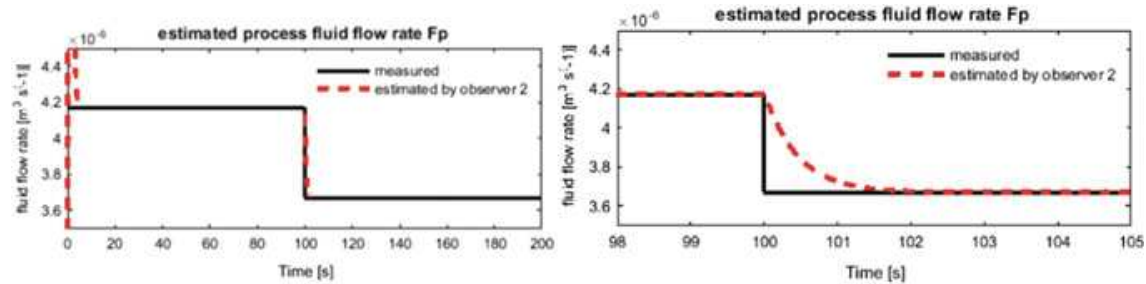

Fig. 4 The computation and estimation of process fluid flow rate; solid line is the computed value $\mathrm{F}_{\mathrm{p}}$, dash line is the estimated one $\hat{\mathrm{F}}_{\mathrm{p}}$
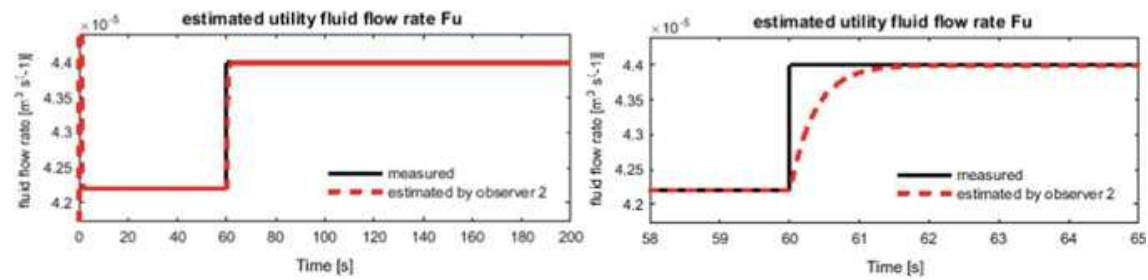

Fig. 5 The computation and estimation of utility fluid flow rate; solid line is the computed value $\mathrm{F}_{\mathrm{u}}$, dash line is the estimated one $\hat{\mathrm{F}}_{\mathrm{u}}$

similar result is obtained in the estimated $\hat{\mathrm{T}}_{\mathrm{u}}$ of utility fluid in Fig. 3. It is shown that the measured $\mathrm{T}_{\mathrm{u}}$ drops 0.2 and $0.5{ }^{\circ} \mathrm{C}$ at $60 \mathrm{~s}, 100 \mathrm{~s}$ respectively. The estimated $\hat{\mathrm{T}}_{\mathrm{u}}$ in dash line tracks $\mathrm{T}_{\mathrm{u}}$ after observer converges. The simulation curve indicates that the observer proposed is proper for tracking system performances.

As shown in Fig. 4, in the first place, the estimated process fluid flow rate $\hat{F}_{p}$ in dash line converges to the simulated value $\mathrm{F}_{\mathrm{p}}$ in solid line after transient response. After that, at $100 \mathrm{~s}$, the simulated $\mathrm{F}_{\mathrm{p}}$ in solid line decrease unexpectedly, fortunately, the estimated value in dash curve gives a quick response to the variation, and it takes $1.5 \mathrm{~s}$ to track $\mathrm{F}_{\mathrm{p}}$ again. The decrease implies parameter changes in process fluid actuator which satisfied the assumption. Figure 5 demonstrates the results for utility fluid flow rate. At time $60 \mathrm{~s}$, as expected, the simulated utility fluid flow rate in solid line jumps. It also proves in Fig. 5 that the estimated utility fluid flow rate $\hat{\mathrm{F}}_{\mathrm{p}}$ in dash line tracks well $\mathrm{F}_{\mathrm{p}}$ in solid line.

Now, it is clear that the proposed interconnected observer is effective even the unknown connection is time-varying either individually or simultaneously. Therefore the proposed observer proves the capacity of performance monitoring, as well as estimation of unknown connection of an interconnected system. 


\section{Conclusion}

The paper considers the issues of both state and unmeasured interconnection estimation for a class of interconnected dynamic system. To achieve this purpose, the unknown outputs information of the latter subsystem are replaced by their estimation through the observer proposed in the former subsystem. Moreover, an extended high gain observer is considered to exactly estimate the states of the former subsystem subject to unknown inputs. While through computing the derivatives of the output vectors in the latter subsystem, the unknown input can be expressed as a function of the inputs, derivatives of the inputs and the states of the actuator subsystem. Numerical simulation examples are given to illustrate the effectiveness of the proposed methods.

Acknowledgements This work was supported by Science and Technology Foundation of Guizhou Province, China ([2016]1053), and Key Project of Science and Technology Foundation of Guizhou Province, China ([2016]2302). And [2017]5788.

\section{References}

1. Yang, J., Zhu, F., Yu, K., Bu, X.: Observer-based state estimation and unknown input reconstruction for nonlinear complex dynamical systems. Commun. Nonlinear Sci. Numer. Simul. 20(3), 927-939 (2015)

2. Besançon, G., Hammouri, H.: On observer design for interconnected systems. J. Math. Syst. Estimation Control 8(3), 1-26 (1998)

3. Vijay, P., Tade, M.O., Ahmed, K., Utikar, R., Pareek, V.: Simultaneous estimation of states and inputs in a planar solid oxide fuel cell using nonlinear adaptive observer design. J. Power Sources 248, 1218-1233 (2014)

4. Djeghali, N., Djennoune, S., Bettayeb, M., Ghanes, M., Barbot, J.P.: Observation and sliding mode observer for nonlinear fractional-order system with unknown input. ISA Trans. 63, 1-10 (2015)

5. Farza, M., M'Saad, M., Menard, T., Fall, M.L., Gehan, O., Pigeon, E.: Simple cascade observer for a class of nonlinear systems with long output delays. IEEE Trans. Automat. Control 60, $3338-3343(2015)$

6. Keliris, C., Polycarpou, M.M., Parisini, T.: A robust nonlinear observer-based approach for distributed fault detection of input-output interconnected systems. Automatica 53, 408-415 (2015)

7. Sandberg, H., André, H., Johansson, K.H.: Distributed fault detection for interconnected second-order systems with applications to power networks consensus protocols in practice. In: First Workshop on Secure Control Systems (SCS), Stockholm (2010)

8. Grip, H.F., Saberi, A., Johansen, T.A.: Observers for interconnected nonlinear and linear systems. Automatica 48(7), 1339-1346 (2012) 
9. Dashkovskiy, S., Naujok, L.: Quasi-ISS/ISDS observers for interconnected systems and applications. Syst. Control Lett. 77, 11-21 (2015)

10. Antonio Susto, G., Krstic, M.: Control of PDE-ODE cascades with Neumann interconnections. J. Franklin Inst. 347(1), 284-314 (2010)

11. Théron, F., Anxionnaz-Minvielle, Z., Cabassud, M., Gourdon, C., Tochon, P.: Characterization of the performances of an innovative heat-exchanger/reactor. Chem. Eng. Process. Process Intensification 82, 30-41 (2014) 